\title{
Evaluation of the Effect of Subsidies on the Production Capability of Land in Selected Regions of the Czech Republic
}

D. Pletichová, Z. Gebeltová

Faculty of Economics and Management, Czech University of Life Sciences Prague, Czech Republic

\section{Anotace}

Pokles produkční schopnosti půd ovlivňuje tvorbu důchodů farmářů, efektivní využití zemědělské půdy, její kvalitativní i kvantitativní degradaci i konkurenceschopnost českého zemědělství. Z výsledků výzkumu UZEI Praha vyplývá, že roční ekonomická ztráta vlivem poklesu kvality půdy v ČR ve sledovaném období let 2009-2012 je přibližně 385 mil. Kč (MZe, 2012a). Cílem článku je zhodnotit souvislosti mezi změnou kvality půdy a vybranými dotacemi, které by měly primárně ovlivňovat efektivní využití zemědělského půdního fondu a trvalou udržitelnost produkční schopnosti. Ve výzkumu byla použita korelační analýza a metoda komparace. Vztah mezi výší vyplácených dotací (SAPS a TOP-UP, AEO, LFA) a změnou produkční schopnosti půd (změna HRRE) nebyl potvrzen. Statisticky významný vztah byl zjištěn pouze u dotací NATURA 2000.

\section{Klíčová slova}

Zemědělský půdní fond, BPEJ, degradace půdy, udržitelné zemědělství, Program rozvoje venkova, greening, public goods.

\begin{abstract}
A decline in the production capability of land affects the creation of farmers' revenues, the effective utilization of agricultural land, its qualitative and quantitative degradation, as well as the competitiveness of Czech agriculture. The results of the IAEI Prague research show that the annual economic loss due to a decline in the quality of land in the Czech Republic within the analyzed period of the years 2009-2012 is approximately CZK 385 mil. (MoA, 2012a). The aim of the article is to evaluate the potential connections between the change in the quality of land and selected subsidies that should primarily be affecting the effective utilization of agricultural land and the continual sustainability of its production capability. In the research, the methods of correlation and comparison were used. The relationship between the amount of paid subsidies (SAPS+TNA, AEM, LFA) and after changing the production ability of soils (difference GARE) was not confirmed. A statistically significant relationship was found only in the subsidies NATURE 2000.
\end{abstract}

\section{Keywords:}

Agricultural land fund, Bonited Soil-Ecological Units /BSEU/, soil degradation, sustainable agriculture, Rural Development Program, greening, public goods.

Pletichová, D. and Gebeltová, Z. (2015) "Evaluation of the Effect of Subsidies on the Production Capability of Land in Selected Regions of the Czech Republic", AGRIS on-line Papers in Economics and Informatics, Vol. 7, No. 4, pp. 111 - 122, ISSN 1804-1930.

\section{Introduction}

\section{Historical overview}

According to the OECD definition (1996), support is understood to mean every intervention controlled by a public authority that causes a distortion of the market by decreasing the production costs of a given good or service or increasing its price. Support is such intervention from which benefits only arise for a certain group of entities, and not for society as a whole.

Inappropriately provided subsidies into agriculture can affect a decrease in, as well as the quality of agricultural land and thereby also 
the competitiveness of agriculture. The state and farmers are still, up to the present time, dealing with the negative effects of agricultural support provided within a centrally planned economy. Subsidies supported an ineffective structure of agricultural production and bad treatment of the highest quality land.

The goal of the centrally planned agricultural policy was maximum self-sufficiency in temperate zone foods (approximately 98\%), which led, in view of disposable resources of agricultural land in Czechoslovakia, to: (1) ineffective farming with high intensity of agricultural production, (2) soil degradation, (3) decreases of high quality land for construction investments, etc. Agricultural subsidies drained financial resources away from the state budget in the form of a negative sales tax as part of a "cheap food" policy.

\section{Basic overview}

Decoupled direct payments linked to land positively affect the amount of the price of land as well as the amount of rent. Subsidies increase income from agricultural production and thereby increase demand for input, including land (Featherstone and Baker, 1988). Economic effectiveness is positively linked with the size of the farm. Studies in Slovenia have led to the conclusion that the expansion of a farm can contribute to an increase in the economic productivity of the agricultural sector. The number of very small farms (less than $1 \mathrm{ha}$ ) continues to increase. Their high performance, as far as allocation effectiveness and profitability are concerned, is given advantages through the provision of generous subsidies, primarily on the basis of non-production criteria (Bojnec and Latruffe, 2013). If direct payments are actively used in the production of agricultural cultures, they have a positive impact on tenants of agricultural land as well as landowners, who have the opportunity to participate in the revenues from the support provided to tenants (Ryan et al., 2001, Patton et al., 2008). The index of the dependence of the sector on subsidies is the ratio of costs and revenues without the inclusion of subsidies. It measures the ability of the sector to generate profit from its own resources. A ratio of costs and revenues without the inclusion of other subsidies for production exceeding values of $100 \%$ presents a risk of dependence on subsidies. Slovakia and the Czech Republic exceed such a threshold value on a long-term basis. In the EU (15) in the year 2008, the index reached a value of $92.5 \%$, in Germany $100.4 \%$, in Slovakia $108.8 \%$, and in the Czech Republic 117.3\%. A greater level of dependence of agriculture on subsidies was seen only in Finland. On the other hand, in Poland, the index only reached $80.1 \%$ (CSO, 2010).

Authors Ciaian and Swinnen (2006) point out the positive effect of the policy of decoupling payments on the land market, arising through an increase in formalized relations between parties as far as land ownership is concerned. On the other hand, other authors draw attention to the fact that payments in support of income reduce funds reallocated in the direction of prospering farms and, at the same time, help to maintain the activity of economically weak farms (Viaggi et al., 2010).

The study of Lapka et al. (2011) compares the role of agricultural subsidies in the area of the development of rural areas in the Czech Republic before and after accession to the European Union (EU) in 2004. The results of an empirical case study show positive changes, associated with participation in joint agricultural policy (CAP). Despite an improvement, farmers continue to cite two main deficiencies and limitations - challenging administrative procedures and changes in program rules. Subsidies for the environment in the Horizontal Rural Development Plan 2004-2006 had an effect on the stabilization of the livelihood of the inhabitants of rural areas.

Ecological agriculture is an alternative to intensive agriculture, which substantially affected the character of the countryside primarily in the second half of the 20th century. In the Czech Republic, ecological agriculture has been developing since 1989. Ecological agriculture is such farming that heeds the environment and its individual elements by restricting or banning the use of substances and methods that burden, pollute or contaminate the environment or increase risks of the contamination of the food chain, and which heeds, to an increased extent, the external life manifestations and behavior and welfare of raised farm animals. The basis of ecological farming is healthy soil. The soil nourishes plants and is therefore also a prerequisite for our health (Antoušková and Kř́stková, 2007, Homolka and Koukolová, 2012). Organic (ecological) agriculture is found both in the United States, as well as in Europe. In the United States, the development of ecological agriculture is driven by the market and depends upon the state and industrial promotion. National policy focuses on the development of standards 
for the management of production, processing and labeling of ecologically produced foods with the goal of facilitating the exchange of information on the market (Lohr and Salomonsson, 2000). Lampkin and Padel (1994) studied programs of financial support for a transition from a conventional method of farming to an ecological method in the years of 1987-1992 in Denmark, Sweden, Norway, Finland, Switzerland, Austria and Germany. The majority of direct subsidies were provided for a limited period of time (3 years - during conversion), and required complete transformation of at least a part of the farm. Support of ecological production is justified by the protection of the environment and objectives to decrease the volume of production.

The main merit of organic foods is that they do not contain any foreign chemical substances and residues of pesticides, because their use is forbidden in ecological agriculture. It cannot be claimed with certainty that organic foods are healthier, but it can be claimed that they have a more positive effect on the health of the consumer when compared to conventional foods (Dlouhý and Urban, 2011). Ecological agriculture has more positive effects on the protection of natural elements and on the countryside than conventional agriculture. Biodiversity of flora and fauna on arable land areas, permanent grass growth, edges of fields and in surrounding biotopes is greater in ecological agriculture than in conventional agriculture. The diversity of crops grown is also higher in businesses farming ecologically in comparison to conventional ones (Šarapatka et al., 2006).

The research of Štolbová et al. (2012) analyzes the economic results of small and large farms in LFA within the Czech Republic and evaluates the impact of current measures for disadvantaged areas where the distribution of EU payments is aimed at grass growth, regardless of the size of the agricultural business within the Czech Republic.

Within the new program period of 2014 - 2020 as part of the Rural Development Program, Ecological Agriculture (EA) will be conducted as an independent measure. Further, entry into the measures will be allowed only for farmers without concurrent conventional production, with the exception of cultures that cannot be farmed ecologically according to the law on ecological farming, e.g. a pond. Payments will be provided only to those applicants who fulfill the condition of a so-called "active farmer" (MoA, 2014a).
The payment for mountain LFA from the year 2015 in the Czech Republic will not be provided only for grass growth, as was the case until the year 2014 inclusive, but rather, for all agricultural land defined as mountain LFA (MoA, 2014b).

Within the new program period (2014-2020), subsidies for land are provided through the Rural Development Program (6 priorities). The reform of joint agricultural policy for the period of 2014-2020 includes the reduction of support for agriculture. For example, financial resources from the EU for the Rural Development Program will be reduced nearly to a half (from 3.6 billion Euro for the years 2007-2013 to 1.9 billion Euro for the years 2014-2020 (EUROPROJECT, 2014).

A new element of the reformed CAP, which should contribute to a decline in the degradation of agricultural land, is so-called "greening". In the past, we have also seen direct payments that had as a prerequisite the fulfillment of certain conditions (cross-compliance) (MoA, 2014c).

The amendment to Act No. 334/1992 Coll., on the Protection of the Agricultural Land Fund, as amended by Act No. 41/2015 Coll., approved by the Cabinet, has as its main objective to protect agricultural land against its removal from the agricultural land fund $/ \mathrm{ALF} /$ and to maintain its production capability. However, decreasing levies for the annexation of agricultural land from agricultural primary production, according to the amendment to such Act, favors the economic aspect over the ecological aspect. Not even a change in the Civil Code (from 1 January 2014) guarantees that the user of agricultural land (tenant farmer) will be a good farmer and will endeavor to maintain the production capability of land.

The effectiveness of subsidies for land can be evaluated according to decreasing land fertility, high decreases of, oftentimes, very high quality agricultural land, which is irretrievably excluded from the agricultural land fund of the Czech Republic - approximately 12 ha per day (MoA, 2012b).

The EU subsidy system should be focusing primarily on: (1) the protection of land against its degradation, (2) the support of the production of quality foods in a sufficient amount and structure, (3) the inspection of their quality, (4) the protection of the environment and the character of the countryside. Other government functions, i.e. non-production functions, are derived from the fundamental 
function of agriculture.

Agricultural subsidies should be set up in such a way so that the farmer does not adjust their activity to the subsidies, but rather, to the effective utilization of resources in the specific natural conditions.

The goal of the article is to evaluate the effect of selected subsidies on a change in the quality of land, which should primarily be affecting the effective utilization of agricultural land and impacting upon the continual sustainability of the production capability of land.

\section{Materials and methods}

\section{Primary data}

i. Yearbook of the Agricultural Land Fund, 2007-2011, Czech Office for Surveying, Mapping and Cadastre /COSMC, 2007-2011/

ii. Informations of the State Agricultural Intervention Fund /SAIF, 2008-2011/

iii. Database AGROREGISTER, Czech Statistical Office, /CzSO, 2008-2011/

\section{Secondary data}

i. Report on the State of Agriculture in the Czech Republic, Ministry of Agriculture, Prague, 2012. /MoA, 2012a/

ii. Situation and Outlook Report for Land, Ministry of Agriculture, Prague 2012. /MoA, 2012b/

iii. Action Plan for Organic Farming 2011-2015, Ministry of Agriculture, Prague 2011.

\section{Used relationships, methods and procedures}

The basis for evaluating the effect of subsidies on the production capability of land in the Czech Republic are the results of research by IAEI Prague. Such research pertains to the quantification of changes in land quality within individual regions of the Czech Republic (NUTS-3) within the analyzed period of the years 2009-2012 (Voltr, in: MoA, 2012a).

When evaluating changes in the value of the land, updated information was used for Bonited SoilEcological Units (BSEU) in the territories, where the complex land adjustment (CLA) was done. It considers disclosure of land, erosion control, water management measures and ecological stability of the territory.
Updating of Bonited Soil- Ecological Units of farmland leads to a reassessment of its production abilities and it is expressed in rent effect (GARE) ${ }^{1}$ and official price of BSEU. In these areas there has been a) a change in the structure of the soil, or b) change in the acreage of agricultural land cadastral area by more than $10 \%$.

Updating of soil ecological units is produced in about $1 \%$ of agricultural land in the Czech Republic per year. The research, used by the authors (Voltr, 2012), covers 2.81\% of the area of the Czech Republic for 2009-2012.

The rent effect is expressed in EUR/hectare of agricultural land. The exchange rate of $\mathrm{CZK} / \mathrm{EUR}$ used is in accordance with the subsidies paid in the respective years, according to the Official Journal of the European Union (2008: 24.660 CZK/EUR; 2009: 25.164 CZK/EUR; 2010: 24.600 CZK/EUR; 2011: 24.754 CZK / EUR).

In order to fulfill the objective of the article, only those subsidies have been selected which can explicitly affect the continual fertility of land:

a) Agri-environment measures (AEM). Measures targeting the sustainable use of agricultural land (1) economical caring of grassland, (2) organic farming, (3) conversion of arable land, which can alleviate the effects of water erosion and protect water courses from chemical pollution; (4) the cultivation of crops that can reduce water and wind erosion, prevent damage to soil structure by sunlight and enrich the soil with humus (Variable: $x_{1}$ ).

b) Less favored areas (LFA). For the payment of subsidies, farmers must guarantee one regular grazing down of permanent grassland or its cutting twice a year. In these areas stocking density is monitored to ensure sound management of utilized land. It is up to $1.5 \mathrm{LU} /$ ha of subsidized agricultural land, at least $0.2 \mathrm{LU} / \mathrm{ha}$ of grassland (Variable: $x_{2}$ ).

c) Nature 2000. Funding of farmland sound management, which will allow the preservation of objects of protection

\footnotetext{
${ }^{1}$ The rent effect $(\mathrm{GARE} / \mathrm{ha})=$ (price of parameterized production - costs of parameterized production) $*$ representation of crop in pricing structure in \%. (Voltr et al., Methodology for valuation of land for quality of Bonited Soil-Ecological Units (BSEU), IAEI Prague, October 2012).
} 
(species of plants, animals and habitat types) (Variable: $x_{3}$ ).

d) Direct payments (SAPS), Transitional national aid - land (TNA). Subsidies paid on a blanket basis per hectare of agricultural land. In the model; they are dealt with comprehensively. They are paid to the company and a tool to determine the extent of the amount of cultivated land is the size of the utilized farmland area. It depends on the decision of the company, how the funds received are exploited. In terms of sustainable soil quality, it is necessary to apply in the field of investment projects aimed eg. on: land protecting machines, equipment to perform operations that prevent soil degradation (Variable: $x_{4}$ ).

e) Information on land quality is given by a difference in the GARE/ha (Variable: y); (Voltr, In: MoA, 2012a).

The article was based on up to 2011, since all the necessary data has not been updated by 2015 .

Used variables are monitored per hectare of subsidized cultivated agricultural land. The amount of cultivated land was drawn from a database of AGROREGISTER. Its extent is identical with the registration of agricultural land in the LPIS - (Land Parcel Identification System for agricultural land) for which subsidies are paid.

Paid subsidies have been identified for the years 2008-2011. This corresponds to years when updating of Bonited Soil-Ecological Units (BSEU) was finalized within the complex land data editing.

The updated BSEU affects the average official prices for individual cadastral areas, which reflects the value of agricultural land. It is caused by a change of value and by measurement changes of agricultural land in the surveyed cadastral districts of the region. This implies that the degradation of soil occurs because of its fertility reduction and its decrease. The technical data to determine the area of measurement of agricultural land in the region was taken from the primary database The Czech Office for Surveying, Mapping and Cadastre.

The objective of the analysis of relations between the variables $\left(x_{1}, x_{2}, x_{3}, x_{4}, y\right)$ is to ascertain whether there is a connection between the said variables - a relationship (correlation), but also what the strength of such a relation is, how close it is, and what its nature is. In order to prove a correlation between variables $x$ and $y$, it is necessary for the null hypothesis (there is no relationship) to be disproven and for values within the matrix in the relevant cell (intersection of $x-y$ ) to be in correlation on the selected level of significance. For greater transparency, such values are set out in red in the matrix (software: STATISTICA, version 12). Besides correlation, regression among the variables is also important. That follows the shape of the nature of the dependence of one variable on another variable, e.g. for the purposes of prediction. Further, basic research methods are utilized in the article, such as the secondary data collection method, analysis and synthesis, comparison and description of the current state of the agricultural land fund. The issue was assessed from a de lege lata standpoint.

\section{Results and discussion}

\section{Support for agribusiness versus development of selected indicators in agriculture}

As of the accession of the Czech Republic to the EU, support of Czech farmers has increased. That has been reflected in the positive economic result of the sector, despite the fact that, when compared to the volume of subsidies in the "old" EU member states, they were substantially lower. Table 1 (see the: appendix) shows that the economic results of doing business in agriculture (2004-2012) were achieved primarily through an increase in subsidies for agribusiness (by $48 \%$ ), with a decrease in the size of agriculture (by $41 \%$ ), a decline in employment (by $39 \%$ ), in the production of the agricultural sector (by $11 \%$ ), of sowing areas (by $7 \%$ )

The development of selected indicators also shows: an increase in subsidies, with the simultaneous decline in agricultural land of approximately 12 ha per day (MoA, 2012b) and a decrease in the production capability of land (IAEI Prague), and causes primarily an improvement of the economics of businesses, rather than having an effect on the continual sustainability of the fertility of agricultural land. This development is unsustainable on a long-term basis. The competitiveness of Czech agriculture cannot be limited by the growth of subsidies, but rather, by the production capability of the land, its effective utilization and protection against degradation. 
2. Quantification of the relationship between subsidies and the quality of agricultural land within the regions of the Czech republic

According to Voltr (MoA, 2012a), "in regard to the evaluation of the economic effect of a change in land quality, it can be assumed that the actualization of inputs at the level of cadastral areas (annexation of agricultural land, re-cultivation of agricultural areas, etc.) affects the growth or decline in the average official price per cadastral area to the same extent and changes in such price are thus caused primarily by degradation processes." On the other hand, however, he acknowledges that some changes in land quality can be brought about by annexations of land, and primarily annexations of quality land. There then remains within the region a lesser extent of land with greater quality.

Information about a change in quality is quantitatively given by the change in the difference of parameterized revenues and costs (GARE). In Table 2 selected subsidies paid in relation to agricultural land are set out and change the production capabilities of soils in the region (expressed GARE).

In order to determine the existence of relationships between variables $x_{1}$ to $x_{4}$ and $y$, a correlation matrix was used within the application of basic statistics. A 5\% level of testing significance was chosen.

As shown in Table 3, a correlation between variables (SAPS, TNA, LFA, AEN and GARE) was not proven. A relationship between the variables was not ascertained on the further tested level of significance of $10 \%$ (further investigation by the authors) either.

Correlation analysis confirmed the relationship between the amount of subsidies paid to Natura 2000 (funded by the Rural Development Programme $/ \mathrm{RDP} /$ ) and the amount of change GARE. The correlation coefficient $(-0.7932)$ is a negative correlation, and the result can be interpreted as follows: in a region where there is a decrease production ability of soils (especially agricultural land management in the vicinity of large cities and growth of the land used for urban infrastructure) funds are invested to care qualitatively about suitable areas of grass and forest vegetation. Correlation describes the behavior of the regions in the use of funds from the RDP so that the natural resources which these regions posses are preserved in the context of sustainable development. The more degraded soils are (loss or decrease in soil fertility

\begin{tabular}{|c|c|c|c|c|c|}
\hline \multirow{2}{*}{\multicolumn{4}{|c|}{ The period of validity of the Decree according to price updates BSEU }} & \multicolumn{2}{|c|}{ Year } \\
\hline & & & & \multicolumn{2}{|c|}{ 2009-2012 } \\
\hline \multicolumn{4}{|c|}{ Period ended landscaping } & \multicolumn{2}{|c|}{$2008-2011$} \\
\hline \multicolumn{4}{|c|}{ Subsidies paid for the period (annual average) } & \multicolumn{2}{|c|}{$2008-2011$} \\
\hline & $\begin{array}{l}\text { AEM } \\
\left(\mathrm{x}_{1}\right)\end{array}$ & $\begin{array}{l}\text { LFA } \\
\left(\mathrm{x}_{2}\right)\end{array}$ & $\begin{array}{c}\text { NATURE } 2000 \\
\left(\mathrm{x}_{3}\right)\end{array}$ & $\begin{array}{c}\text { SAPS+TNA } \\
\left(\mathrm{x}_{4}\right)\end{array}$ & $\begin{array}{l}\text { Value diference } \\
\text { GARE (y) }\end{array}$ \\
\hline Region & & & EUR/ha & & \\
\hline Královehradecký & 175.945 & 40.684 & 27.548 & 0.008 & 8.8943 \\
\hline Jihomoravský & 173.771 & 39.533 & 4.376 & 0.442 & -36.5811 \\
\hline Jihočeský & 184.247 & 61.235 & 48.448 & 0.263 & 1.8573 \\
\hline Karlovarský & 181.644 & 115.846 & 86.287 & 0.030 & 0.142 \\
\hline Liberecký & 174.703 & 93.665 & 55.073 & 0.012 & 12.9452 \\
\hline Moravskoslezský & 181.712 & 65.470 & 47.644 & 0.095 & 9.1601 \\
\hline Olomoucký & 183.849 & 47.124 & 30.061 & 0.010 & -15.0207 \\
\hline Pardubický & 175.171 & 30.930 & 22.395 & 0.013 & 8.7798 \\
\hline Plzeňský & 184.046 & 52.008 & 42.227 & 0.080 & 2.3344 \\
\hline Středočeský & 167.017 & 108.731 & 9.248 & 0.021 & -7.8175 \\
\hline Vysočina & 183.823 & 31.349 & 29.010 & 0.004 & 4.4655 \\
\hline Zlínský & 173.268 & 72.241 & 37.944 & 0.539 & -30.7887 \\
\hline Ústecký & 173.108 & 57.228 & 27.829 & 0.032 & 3.1511 \\
\hline
\end{tabular}

Source: Internal SAIF support database (2008-2011),

Voltr in: MoA (2012a) The exchange rate 2008-2011 the EU Official Journal - see: Methodology.

Table 2: Selected subsidies and the value difference GARE in regions of the Czech Republic in the reporting period (EUR/ha). 


\begin{tabular}{|l|c|c|c|c|c|c|c|}
\hline Variables & \multicolumn{7}{|c|}{ Correlation } \\
\cline { 2 - 8 } & \multicolumn{7}{|c|}{ Marked correlations are significant at the level $\mathrm{p}<0.5000$} \\
\cline { 2 - 9 } & \multicolumn{7}{|c|}{$\mathrm{N}=13$} \\
\cline { 2 - 8 } & Averages & $\begin{array}{c}\text { st. } \\
\text { Deviation }\end{array}$ & $\begin{array}{c}\text { SAPS } \\
\text { and TNA }\end{array}$ & AEN & LFA & $\begin{array}{c}\text { NATURE } \\
2000\end{array}$ & $\begin{array}{c}\text { Difference } \\
\text { GARE }\end{array}$ \\
\hline SAPS and TNA & 177.8696 & 5.61592 & 1 & -0.284297 & 0.504468 & -0.167716 & 0.203123 \\
\hline AES & 62.7727 & 27.99334 & -0.284297 & 1 & 0.522411 & -0.070915 & 0.030424 \\
\hline LFA & 36.0068 & 21.11253 & 0.504468 & 0.522411 & 1 & -0.164182 & 0.345243 \\
\hline NATURE 2000 & 0.1192 & 0.18012 & -0.167716 & -0.070915 & -0.164182 & 1 & -0.793237 \\
\hline Difference GARE & -4.3691 & 15.19639 & 0.203123 & 0.030424 & 0.345243 & -0.793237 & 1 \\
\hline
\end{tabular}

Source: The authors, dates: see Methodology, STATISTICA, version 12

Table 3: Variant 1, The description of relationship between selected subsidies and a production capabilities GARE (EUR/ha).

\begin{tabular}{|c|c|c|c|c|c|c|}
\hline \multirow[t]{4}{*}{ Variables } & \multicolumn{6}{|c|}{ Correlation } \\
\hline & \multicolumn{6}{|c|}{ Marked correlations are significant at the level $p<0.5000$} \\
\hline & \multicolumn{6}{|c|}{$\mathrm{N}=13$} \\
\hline & Averages & st. Deviation & $\begin{array}{c}\text { SAPS } \\
\text { and TNA }\end{array}$ & AEN & LFA & $\begin{array}{c}\text { NATURE } \\
2000\end{array}$ \\
\hline AES & 62.91211 & 28.41785 & 1 & 0.548249 & -0.098447 & 0.04695 \\
\hline LFA & 36.07946 & 21.17168 & 0.548249 & 1 & -0.198255 & 0.35976 \\
\hline NATURE 2000 & 0.11832 & 0.17473 & -0.098447 & -0.198255 & 1 & -0.794808 \\
\hline Difference GARE & -4.34803 & 15.12304 & 0.04695 & 0.35976 & -0.794808 & 1 \\
\hline
\end{tabular}

Source: The authors, dates: see Methodology, STATISTICA, version 12

Table 4: Variant 2, The description of relationship between selected subsidies without SAPS, TNA and a production capabilities GARE (EUR/ha).

because of agricultural production), the more funds are invested in the protection of ecologically valuable sites.

Regression analysis quantified a relationship: $y=-66+3.6052 x_{3}$

Information about regression:

- $\quad$ Significance level $\alpha=5 \%$ (risk measure)

- The coefficient of the variable Natura:

$$
\mathrm{p}=0.001213
$$

- $\quad \mathrm{R}^{2}=0.5955=59.55 \%$

Table 4, var. 2 shows, that even if pursued subsidies without SAPS + TNA (not paid directly for investments into land), relationships between variables were not detected other statistical correlation than var. no 1 . (Table 3 ).

The influences that must be understood as significant in evaluating land quality are the size of annexations of agricultural land for nonagricultural purposes, the intensity of production, compliance with agro-environmental measures (GAEG), compliance with sowing procedures (improving and deteriorating crop), the extent of erosion sowing crops on inappropriate sites etc
Data characterizing the losses of agricultural land in the regions are arranged in descending order. In the South-Moravian region, which should be a "reservoir" of quality land to ensure food self-sufficiency in the Czech Republic, occurs its degradation (Table 2) and significant decline (Table 5). Soils in poorer natural conditions - Liberec Region have its value improved (Table 2 and 5). Excessive losses of agricultural land of higher quality (Table 5, Figure 1) and soil degradation itself have a significant impact on changes in the land value. Both factors have influence on reduction of land value in the regions of South Moravia.

In view of the dissimilarity of natural conditions within the analyzed regions, we can state that the main effect of subsidies on land is still the compensation of differences in the farming of agricultural businesses within the regions of the Czech Republic.

The monitoring changes in the structure of the agricultural land in terms of transfers to non-agricultural land has not been the purpose of this article. But: It can be stated, that a significant impact on the change in soil quality over farmland 


\begin{tabular}{|l|c|c|c|c|c|}
\hline \multirow{2}{*}{ Region } & \multicolumn{2}{|c|}{ Year } & Difference & Difference & $\begin{array}{c}\text { Official average farmland } \\
\text { price of updating BSEU }\end{array}$ \\
\cline { 2 - 6 } & 2007 & 2011 & $($ ha) & $(\%)$ & EUR/m ${ }^{2}$ \\
\hline Královehradecký & 429851 & 426703 & -3148 & 0.732 & 0.339 \\
\hline Jihomoravský & 195172 & 193937 & -1235 & 0.633 & 0.300 \\
\hline Jihočeský & 276622 & 274957 & -1665 & 0.602 & 0.285 \\
\hline Karlovarský & 381770 & 379930 & -1840 & 0.482 & 0.168 \\
\hline Liberecký & 281089 & 279763 & -1326 & 0.472 & 0.272 \\
\hline Moravskoslezský & 493354 & 491150 & -2204 & 0.447 & 0.157 \\
\hline Olomoucký & 411648 & 409911 & -1737 & 0.422 & 0.150 \\
\hline Pardubický & 279073 & 277926 & -1147 & 0.411 & 0.278 \\
\hline Plzeňský & 273028 & 271914 & -1114 & 0.408 & 0.240 \\
\hline Středočeský & 276779 & 275682 & -1097 & 0.396 & 0.256 \\
\hline Vysočina & 665547 & 663087 & -2460 & 0.370 & 0.343 \\
\hline Zlínský & 140306 & 139896 & -410 & 0.292 & 0.222 \\
\hline Ústecký & 124246 & 124061 & -185 & 0.149 & 0.124 \\
\hline
\end{tabular}

Note:

1) The difference, which relates to the period before updating BSEU farmland (31.12.2007) and after (31.12.2011)

2) The average official price for the concerned cadastral territory after updating BSEU (Price Decree Ministry of Agriculture and Ministry of Finance: 2009-2012). Current exchange rate CZK/EUR: 25.800; used in December 31.12. 2012.

Source: Yearbook of the Agricultural Land Fund (2007-2011), COSMC (2007-2011)

Voltr, In: MoA (2012a)

Table 5: Change in area of agricultural land by region Czech Republic.

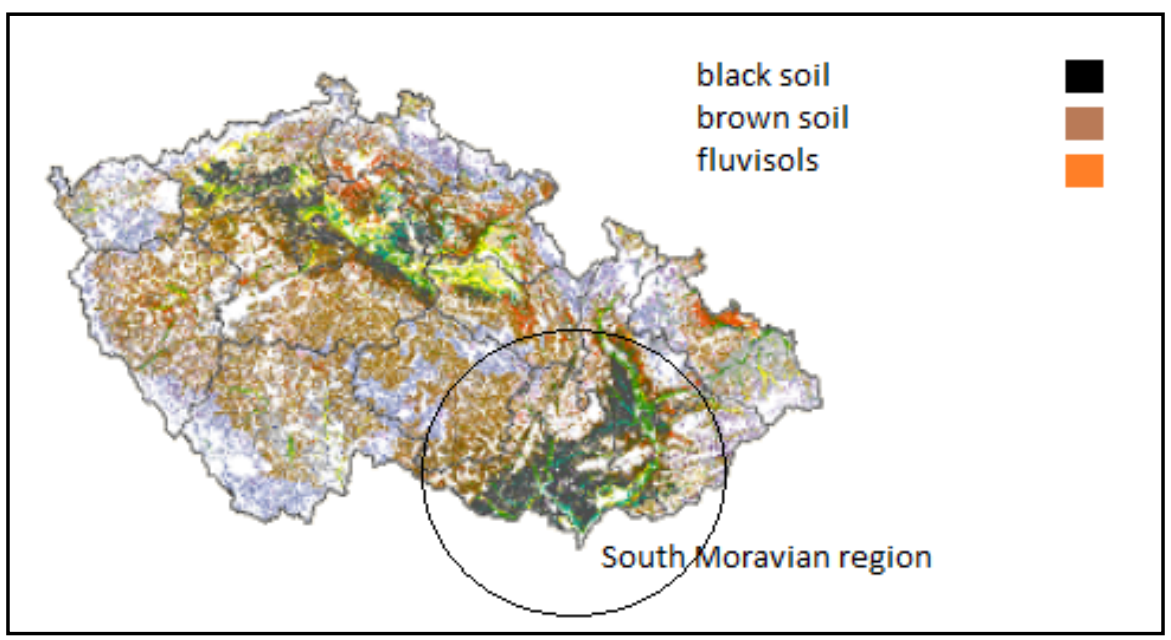

Source: VÚMOP, 2015

Figure 1: Main Soil Types in the Czech Republic.

is caused losses higher quality. If there is such land grabs, e.g. in Jihomoravský Region (-0.732\% for the period 2007-2011), Olomoucký (-0.472\%) and Zlínský Region (-0.633\%), it will be mostly a land of higher quality. There is also greater soil degradation. However, there is no statistical relationship between the amount of decreases of land and the reduction in the production capability of land in the whole file of 13 regions.

The subsidies for pastoral farming (lower soil quality regions: Liberecký, Karlovarský, Jihočeský, Vysočina) affect soil quality positively. There are not explicitly associated with land subsidies, but they cannot be overlooked in the soil assessment.

Primarily the manner of farming on land (e.g. ecological agriculture) has a greater effect on the continual sustainability of the fertility of land than subsidies for land. It is unrealistic, from a long-term standpoint, for negative business income (in production areas) to be compensated 
by operating subsidies. Ecological agriculture, as compared to conventional (industrial) agriculture, produces more positive externalities. It should not be an alternative, but rather, it should be, e.g. in multiple variations of the application of such a system, the norm. The effectiveness of subsidies on ecological agriculture would increase through the payment of investment support for the processing and sale of organic foods directly on the farms that produce such products, so that food and energy are not wasted. The time between the production, processing and consumption of organic products would thus be shortened. The costs for transportation, distribution, etc. would be decreased, which would lead to a reduction in their prices. Subsidies would lead to greater economic independence of ecological farms, an increase in the proportion of organic products of Czech origin and the proportion of ecologically farmed agricultural land/the goal of the Czech Republic for the year 2015 is $15 \%$ of the total area of agricultural land/ (Action Plan, MoA, 2015).

EU in the new programming period 2014-2020 made major interventions into the CAP. Subsidies will be tied to performance and soil protective ecological farming practices (greening).

\section{Conclusion}

i. A correlation between subsidies for land and its production capability was not proven, even at a level of significance of 5\% and $10 \%$. That means that a long-term increase in support linked to land (Table 1, 2, and 3) has more of an effect on the economics of agricultural businesses than on the continual fertility of the land, i.e. harmony between agriculture and the environment. The conditions for a change in the current trend (soil erosion, decreases in agricultural land, a relatively low proportion of permanent grassland, a decline in the numbers of farm animals, etc.) are not being created. The decline in the numbers of farm animals does decrease the production of emissions from the agricultural sector, but negatively affects the content of organic matter in the soil. The structure and stability of organic matter, which is an indicator of land quality, is changing.

ii. Although there is no evidence of an effect of AEM subsidies on change of the production capacity of the soil (there was no statistically significant relationship), the authors believe that these subsidies have their purpose and are desirable. The negative result of the research can be explained by the time data base not large enough. Support AEM is paid to new EU countries since their accession to the EU (2004). Implementation of soil conservation plans could not become evident yet.

iii. It is considered to be a positive fact that it confirmed the statistical correlation between subsidies NATURE 2000 and difference GARE (correlation coefficient $=-0.79$ ). Regions are aware of the loss of soil quality because of agricultural activity and land occupation for the urbanism development, so they try to rescue valuable forest and grassland habitats.

iv. The author recommends: (1) establish a monitoring technologies of cultivation of agricultural land, particularly in the major producing areas of the Czech Republic and monitor the impact of farming on the environment, threats to soil erosion, lack of available moisture, etc. (2) The issue of degradation of farmland, which also concerns other EU member states, resolved at this level and to promote the adoption of a directive on the protection of agricultural land under the European program for the protection of agricultural land resources.

v. It is worth considering whether it would be appropriate to further research focus on "Subsidies for land consolidation". BSEU updates are handled in territories where they enacted comprehensive landscaping. These include the issue of ownership of land holdings, but also agricultural infrastructure or absence of elements of ecological stability of the landscape (corridors, water tank dikes, ditches catch). All this is undoubtedly beneficial for improving the quality of agricultural land. 
Corresponding author:

Ing. Dobroslava Pletichová

Department of Economics, Faculty of Economics and Management

Czech university of Life Sciences Prague, Kamýcká 129, 16521 Prague 6, Czech Republic

E-mail: pletichovad@seznam.cz

Ing. Zdeňka Gebeltová

Department of Economics, Faculty of Economics and Management

Czech university of Life Sciences Prague, Kamýcká 129, 16521 Prague 6, Czech Republic

E-mail: gebeltova@pef.czu.cz

\section{References}

[1] Antoušková, M., Křístková, Z. Finanční dotace pro ekologické zemědělství (Financial subsidies for organic farming), In: Articles Proceedings of International Scientific Conference, Agrarian perspective XIV - Knowledge Economy - Part I, PEF CUA Prague. 2005, p. 43-47. [Online] Available: www.agris.cz/content/files/main_files/70/148468/07antouskova.pdf: [Accessed: 15 October, 2014]. ISBN: 80-213-1372-2.

[2] Bojnec, Š, Latruffe, L. Farm size, agricultural subsidies and farm performance in Slovenia, Land Use Policy. May 2013, Vol. 32, p. 207-217. ISSN 0264-8377.

[3] Ciaian, P., Swinnen, J. F. M. Land market imperfections and agricultural policy impacts in the new EU member states: a partial equilibrium analysis, American journal of Agricultural Economics. 2006, Vol. 88, No. 4, p. 799-815. ISSN 1467-8276.

[4] COSMC (2007-2011). Yearbook of the Agricultural Land Fund, Czech Office for Surveying Mapping and Cadastre. Prague 2008-2012. ISSN 1804-2422.

[5] CzSO. Analýza zemědělství, kapitola: Revenues and expenses. Czech Statistical Office, Prague. 2010. [Online] Available: http://notes3.czso.cz/csu/2010edicniplan.nsf/t/34002F30CD/\$File/213410a6. pdf [Accessed: 10 March, 2014].

[6] CzSO (2008-2011). AGROREGISTER, the primary database of land and businesses, Czech Statistical Office, Prague. 2013.

[7] Dlouhý J., Urban J. Ekologické zemědělství bez mýtů, (Organic farming without myths), Facts about ecological agriculture and bio-foods for media. Czech technologic platform for ecological agriculture. 2011, p. 25. [Online] Available: www.bioinstitut.cz, [Accessed: 18 September 2012]. ISBN 978-80-87371-13-8.

[8] EUROPROJECT. Rural Development Program 2014 - 2020. (Rural Development Program 2014 -2020), 2014. [Online] Available: http://www.europroject.cz/program-rozvoje-venkova-2014-2020, [Accessed: 18 September 2014].

[9] Featherstone, A. M., Baker, T. G. Effects of reduced price and income supports on farmland rent and value, North Central Journal of Agricultural Economics, 1988, Vol. 10, No. 1, p. 177-190. ISSN 0191-9016.

[10] Homolka, P. Koukolová, V. Ekologické zemědělství - produkce zdravých a bezpečných krmiv, (Organic farming - the production of healthy and safe feed), Research Institute of Animal Production, Uhř́něves. 2012. [Online] Available: http://www.vuzv.cz/sites/File/vybor/Ekologicke\%20 zemedelstvi.pdf [Accessed: 20 October 2014].

[11] Lampkin, N. H., Padel, S. Organic farming and agricultural policy in western Europe: An overview. In: Lampkin, N. H., Padel, S., (Ed.), The Economics of Organic Farming, CAB International, Oxon, UK.1994, p. 437-456. 
[12] Lapka, M., Cudlínová, E., Rikoon, J. S., Pělucha, M., Kvetoň, V. Rural development in the context of agricultural "green" subsidies: Czech farmers' responses, Agric. Econ. - Czech. 2011, Vol. 57 , p. 259-271. ISSN 1805-9295.

[13] Lohr, L., Salomonsson, L. Conversion subsidies for organic production: results from Sweden and lessons for the United States, Agricultural Economics. March 2000, Vol. 22, No. 2, p. 133-146, ISSN 1574-0862.

[14] MoA (2005-2013). Report on the State of Agriculture in the Czech Republic, Department of Agriculture, Prague. 2005-2013. ISBN: 978-80-7434-005-5.

[15] MoA (2011). Action Plan for Organic Farming 2011-2015, Department of Agriculture, Prague, 2011. ISBN 978-80-7434-007-9.

[16] MoA (2012a). Report on the State of Agriculture in the Czech Republic, Department of Agriculture, Prague. 2012. ISBN 978-80-7434-005-5.

[17] MoA (2012b) Situation and Outlook Report for Land, Department of Agriculture, Prague, 2012, ISBN 879-80-7434-088-8.

[18] MoA (2014a). Department of Agriculture, Prague. [Online] Available: http://eagri.cz/public/ $\mathrm{web} / \mathrm{mze} / \mathrm{ministerstvo-zemedelstvi/zahranicni-vztahy/cr-a-evropska-unie/spolecna-zemedelska-}$ politika/dotace-na-tzv-ozeleneni-neboli-greening.html, [Accessed: 15 Januar 2015].

[19] MoA (2014b). Department of Agriculture, Prague, online: June 2014, [online] Available: http:// eagri.cz/public/web/mze/dotace/program-rozvoje-venkova-na-obdobi-2014/aktuality/. [Accessed: 15 Januar 2015].

[20] MoA (2014c). Dotace pro oblasti s přírodními či jinými zvláštními omezeními (tzv. LFA) a platby na tzv. ozelenění neboli greening, (Subsidies for areas with natural or other specific constraints), [online] Available: http://eagri.cz/public/web/mze/dotace/program-rozvoje-venkova-naobdobi-2014/aktuality/dotace-pro-oblasti-s-prirodnimi-ci.html. [Accessed: 15 Januar 2015].

[21] OECD. Subsidies and environment: exploring the linkages. In: CENIA (2011). Veřejné podpory v ochraně životního prostředí v ČR a přístupy k jejich posuzování. 1996, [Online] Available: http://www1.cenia.cz/www/sites/default/files/verejne_podpory.pdf [Accessed: 10 May 2014]. ISBN: 92-64-14822-1,

[22] Ryan, J., Barnard, C. Collender, R. Government payments to farmers contribute to rising land values, Agricultural Outlook. 2001, p. 22-26. ISSN 1999-1142.

[23] SAIF. State Agricultural Intervention Fund, 2015, [Online] Available: http://www.szif.cz/cs/ jednotna-zadost. [Accessed: 15 November, 2014].

[24] SAIF, SAIF's internal support database (2008-2011).[Online] Available: http://www.szif.cz/cs/. [Accessed: 10 December 2014].

[25] Šarapatka, B., Urban, J. Ekologické zemědělství v praxi. (Organic farming in practice). PRO-BIO Svaz ekologických zemědělců, Šumperk. 2006, p. 502, ISBN 978-80-903583-0-0.

[26] Štolbová, M., Míčová, M. The farm size in the less-favoured areas and the economy of support spending on public goods production in the case of the Czech Republic, Agric. Econ. - Czech, 2012, Vol. 58, p. 482-496. ISSN 1805-9295.

[27] Viaggi, D., Raggi, M., Gomez y Paloma, S. An integer programming dynamic farm-household model to evaluate the impact of agricultural policy reforms on farm investment behaviour, European Journal of Operational Research, 2010, Vol. 207, No. 2, p. 1130-1139. ISSN 0377-2217.

[28] Voltr, V., Hruška, M., Šařec, P., Leština, J., Froněk, P. Metodika ocenění půdy pro bonitované půdně-ekologické jednotky (BPEJ), (Methodology for valuation of land for quality of Bonited SoilEcological Units (BSEU). IAEI, Prague. October 2012 [Online], Available: http://www.uzei.cz/ data/usr_001_cz_soubory/metodika_oceneni_bpej.pdf, Accessed: 10 March 2014]. 
[29] VÚMOP v.v.i. Research Institute for Soil and Water Conservation, 2015. [Online] Available: http://bpej.vumop.cz/. [Accessed: 10 July 2015].

\section{Appendix}

\begin{tabular}{|c|c|c|c|c|c|c|}
\hline & \multicolumn{5}{|c|}{ year } & \multirow{2}{*}{$\begin{array}{c}\text { index } \\
2004=100\end{array}$} \\
\hline & 2004 & 2006 & 2008 & 2010 & 2012 & \\
\hline $\begin{array}{l}\text { Share of agriculture in GVA (\%), current } \\
\text { prices }\end{array}$ & 2.63 & 1.94 & 1.93 & 1.09 & 1.55 & 0.59 \\
\hline Economically active in agriculture (\%) & 4.3 & 3.08 & 2.87 & 2.64 & 2.62 & 0.61 \\
\hline $\begin{array}{l}\text { Wage disparity in agriculture/national } \\
\text { economy }(\%)\end{array}$ & 71.7 & 76.1 & 79.1 & 77.8 & 78.2 & 1.09 \\
\hline $\begin{array}{l}\text { Agricultural industry output (mil. CZK, } \\
\text { constant prices of 2000) }\end{array}$ & 111286 & 101461 & 110670 & 97938 & 98983 & 0.89 \\
\hline $\begin{array}{l}\text { Net value added (mil. CZK, constant prices } \\
\text { of 2000) }\end{array}$ & 27382 & 19362 & 25370 & 17198 & 17921 & 0.65 \\
\hline The factor income (mil. CZK, current prices) & 30985 & 34628 & 40642 & 35662 & 47192 & 1.52 \\
\hline Net operating surplus (mil. CZK) & 11825 & 11003 & 14586 & 11678 & 22364 & 1.89 \\
\hline $\begin{array}{l}\text { Support to the agrarian complex, total } \\
\text { (mil. CZK) }\end{array}$ & 28031 & 35739 & 37692 & 44857 & 41494 & 1.48 \\
\hline of which Czech Republic & 16810 & 17166 & 16506 & 15287 & 11160 & 0.66 \\
\hline of which EU & 11221 & 18573 & 21186 & 29570 & 30334 & 2.70 \\
\hline Net value added / AWU (thous. CZK) & 312.9 & 310.9 & 374.9 & 383.0 & 504.6 & 1.61 \\
\hline $\begin{array}{l}\text { Entrepreneurial income } \\
\text { (mil. CZK, current prices) }\end{array}$ & 8558 & 6835 & 10143 & 7645 & 16444 & 1.92 \\
\hline Agricultural foreign trade balance (mil.CZK) & -32295.5 & -34015.7 & -24117.0 & -34643.6 & -24834.3 & 0.77 \\
\hline Agricultural land area, 31.12. (ha) & 4269227 & 4259481 & 4249179 & 4238975 & 4229167 & 0.99 \\
\hline Area of of arable land (ha) & 3062019 & 3047250 & 3032448 & 3016858 & 3000390 & 0.98 \\
\hline TTP (ha) & 970623 & 973791 & 977989 & 982776 & 989293 & 1.02 \\
\hline Not sown area, fallow land (thous. ha) & 45 & 44 & 23 & 45 & 33 & 0.73 \\
\hline Total area under cultivation (thous. ha) & 2658 & 2587 & 2545 & 2488 & 2477 & 0.93 \\
\hline $\begin{array}{l}\text { The area of agricultural land in organic } \\
\text { agriculture / total area of farmland (\%) }\end{array}$ & 6.16 & 6.61 & 8.04 & 10.55 & 13.9 & 2.26 \\
\hline $\begin{array}{l}\text { Consumption of mineral fertilizers NPK } \\
\text { (kg of pure nutrients / ha of agricultural land) }\end{array}$ & 99.4 & 98.5 & 110.6 & 93.1 & 117.6 & 1.18 \\
\hline Livestock (thous. pcs) & 1428 & 1374 & 1402 & 1349 & 1354 & 0.95 \\
\hline
\end{tabular}

Source:

MaA (2011). Action Plan for Organic Farming 2011-2015, Department of Agriculture, Prague, 2011

MoA (2005-2013). Report on the State of Agriculture v the Czech Republic, Department of Agriculture, Prague

Table 1: Selected indicators of the agricultural sector in the years 2004-2012. 